\title{
MORFOLOGIA DO SISTEMA VISUAL
}

\author{
MORPHOLOGY OF THE VISUAL SYSTEM
}

Harley E. A. Bicas

Docente do Departamento de Oftalmologia e Otorrinolaringologia da Faculdade de Medicina de Ribeirão Preto da Universidade de São Paulo.

Correspondência: Harley E. A. Bicas. Departamento de Oftalmologia e Otorrinolaringologia da Faculdade de Medicina de Ribeirão Preto da Universidade de São Paulo, 14048-900 - Ribeirão Preto - SP - Brasil. Fax: (016) 633-0186.

BICAS HEA. Morfologia do sistema visual. Medicina, Ribeirão Preto, 30: 7-15, jan./mar. 1997.

RESUMO: Descreve-se a morfologia das diversas estruturas determinantes da percepção visual, de acordo às respectivas funções desempenhadas: as do órgão de recepção do sinal luminoso, compreendendo o sistema óptico (córnea, câmara anterior, cristalino, corpo vítreo), seus suplementos (íris e corpo ciliar) e o sistema de nutrição e proteção (coróide e esclera). Em seguida, são examinadas a da transdução sensorial, isto é, a de transformação da luz em sinal neural (retina) e as de transmissão dele (nervo óptico, quiasma, tratos ópticos, corpos geniculados laterais e radiações ópticas). $\mathrm{E}$, por fim, as de decodificação dos sinais da sensação visual a uma percepção (córtex visual) e as de conexão desse conhecimento adquirido com outros (áreas de associação) para a compreensão de todos.

Dessa forma sistematizada e abrangente, caracteriza-se a importância relativa de cada estrutura, no processo de integração visual.

UNITERMOS: Estruturas Oculares. Vias Visuais. Visão.

O que se pode entender por sistema visual, em sua inteireza, não tem limites precisos, pois isso quase pode ser configurado como compreendendo todo o "cérebro". De fato, apesar de bem determinado em seu órgão de recepção da luz (o olho) e de transdução a sinais neurais (a retina), em suas vias "periféricas"de transmissão (nervos ópticos, quiasma, tratos ópticos, corpos geniculados laterais e radiações ópticas) até o local de recepção e decodificação desses sinais, então transformados em "percepção" visual (o córtex occipital), não se pode dizer que o processo da visão aí termine. A outras partes (córtices parietais e temporais) se atribui a interação dessa percepção com outras informações, de modo que daí resulte uma verdadeira compreensão daquilo que se vê. Dividiremos, pois, o assunto de acordo à função que cada estrutura desempenha.

\section{I - O ÓRGÃO DE RECEPÇÃO DO SINAL LUMINOSO}

Pode ter parecido uma esquisitice a referência, pouco acima, a "olho e retina", continente e conteúdo, em separado. Mas há quem entenda a retina como uma expansão do sistema nervoso central para dentro do olho e, pelo menos funcionalmente, essa consideração está justificada, como veremos.

De fato, o olho, como estrutura, é todo voltado a alimentar a retina (coróide), dar-lhe sustentação e forma (corpo vítreo, esclera) e ajudar seu desempenho, como sistema óptico (córnea e cristalino, como lentes; íris, como diafragma para entrada da luz; esclera, fechando uma câmara escura). Por si mesmo, não muda substancialmente a natureza do estímulo (luz) que, partindo de um objeto, atravessa o espaço e depois seu interior até atingir a retina. Por isso é que se fala 
em estímulo distal (o objeto de onde provém a luz) e estímulo proximal (a luz, eventualmente transformada, ao atingir a retina).

\section{A - O sistema óptico}

Requer quatro capacitações fundamentais: a de transmissão fiel, não distorcida, das relações de intensidade (brilho), forma e cores dos estímulos, devendo, por isso, ser transparente; a de formação da imagem sobre a retina (ou focalização), devendo, por isso, ser refringente; a de mudança dessa focalização, com a variação de distância do objeto estimulante (ou acomodação), devendo, por isso, ser ajustável; e a de regulação da quantidade de luz incidente que pode estimular a retina. No que respeita à passagem de luz, de anterior (ventral) para posterior (dorsal), as estruturas são:

\section{1 - Córnea}

Estrutura transparente, abaulada, cobrindo o sexto anterior do olho, macroscopicamente representada por uma face anterior, com raio de curvatura $7,7 \mathrm{~mm}$ e uma posterior, com raio de curvatura $6,8 \mathrm{~mm}$. É, pois, um menisco divergente que, quando isolado (no ar), tem um poder dióptrico -5.5 D, mas que, "in situ", separando o ar (índice de refração $\left.\mathrm{n}_{1}=1,000\right)$ e o aquoso $\left(\mathrm{n}_{2}=1,336\right)$ passa a exercer um poder dióptrico de cerca de $+43 \mathrm{D}$. Como calota, tem, em sua base, um diâmetro de cerca de $12,5 \mathrm{~mm}$. A transição com a estrutura adjacente (esclera), chamada limbo esclerocorneal, limbo corneoescleral, ou simplesmente limbo, não é brusca: a delicada e regular distribuição das fibrilas colágenas em seu estroma, garantindo-lhe a transparência, desorganiza-se progressivamente para formar a esclera. Na verdade, as duas estruturas são de formação embrionária diferente: a córnea origina-se do ectoderma superficial (epitélio) e do mesoderma (endotélio), com um estrato acelular entre eles (estroma), enquanto a esclera vem do ectoderma neural. Em seu centro, a espessura da córnea é de cerca de $0,6 \mathrm{~mm}$, ficando pouco maior perto do limbo (cerca de $1 \mathrm{~mm}$ ). Por outro lado, a curvatura da córnea, fundamental em seu "centro" (ápice) para a refringência dos raios luminosos, diminui em regiões mais periféricas. A córnea é estrutura avascular (sua nutrição se dá pelo humor aquoso, por difusão) mas tem filetes nervosos, muito finos e também transparentes (originados da divisão oftálmica do trigêmeo, chegando ao olho pelos nervos ciliares), que lhe garantem uma enorme sensibilidade tátil e dolorosa, considerada a maior de todo o organismo. Tem, em sua composição, cinco camadas:

\section{a - Epitélio}

Pavimentar, com várias camadas de células, tanto mais achatadas quanto mais superficiais, tem cerca de 50 a $100 \mu$ de espessura. No limbo, continua-se com o epitélio da mucosa conjuntival. O epitélio é recoberto por uma fina película de lágrima, que lhe confere proteção contra o dessecamento. Aliás, é sobre essa película líquida (e não sobre o epitélio) que se assentam as lentes de contato.

\section{b - Membrana de Bowman}

Elástica, hialina, acelular, de uns 10 a $12 \mu$ de espessura. Muito resistente a traumatismos e invasões bacterianas.

\section{c - Estroma ou parênquima}

Formado por fibrilas laminares de colágeno, regularmente dispostas, paralelas à superfície, transparentes, amalgamadas sobre uma matriz mucóide. Corresponde a cerca de $90 \%$ de toda a espessura corneal e, quando lesado, reorganiza-se de modo irregular, formando cicatrizações esbranquiçadas (leucomas).

\section{d - Membrana basal ou de Descemet}

Hialina, elástica, ainda mais resistente que a membrana de Bowman, embora mais fina ( 5 a $7 \mu$ ), mas que cresce incessantemente, passando de umas 2 a $3 \mu$, no nascimento, a cerca de dez vezes mais, no velho. Essa membrana, pois, se regenera quando lesada, ao contrário da de Bowman (que, quando rompida, também deixa como cicatriz um processo fibrótico opaco).

\section{e - Endotélio}

Unicelular $(5 \mu)$ continua-se com o epitélio que recobre a íris. Também se regenera, como o epitélio. Em contato com o humor aquoso e a ele permeável, o endotélio dá passagem a nutrientes às outras estruturas da córnea. Como a membrana de Descemet, não recebe inervação.

\section{2 - Câmara anterior}

Entre a córnea (anteriormente, ou "acima") e a íris (no seu oríficio, a pupila) mais o cristalino (posteriormente, ou "abaixo"), o espaço $(0,25 \mathrm{ml})$ enche-se 
com o humor aquoso, um transudato do epitélio ciliar, na câmara posterior $(0,06 \mathrm{ml})$ (ver Figura 1$)$ com composição semelhante à da linfa (mas com menos albumina, não se coagulando) e índice de refração bem próximo do da água $(\mathrm{n}=1,336)$. $\mathrm{O}$ humor aquoso tem não só a função de nutrir córnea e cristalino, como a de manter uma pressão hidrostática conveniente para o olho (valores normais em torno de 12 a $19 \mathrm{mmHg}$ ). Constantemente produzido $(2,1 \mu \mathrm{l} / \mathrm{min}$, cerca de $0,7 \%$ de seu volume total), passa da câmara posterior à anterior e daí sai pelo ângulo cameral (formado na junção da córnea com a raiz da íris) filtrando-se por uma estrutura porosa (o trabeculado) ao canal de Schlemm (que circunda toda a córnea, sob o limbo), em seguida drenado às veias "aquosas" de Ascher, parte, já, da circulação sanguínea de retorno, coletada pelas veias ciliares anteriores.

\section{3 - Cristalino}

Também estrutura transparente, sem vasos e nervos, mas constituída por fibrilas celulares, formando lamelas concêntricas. Essas fibrilas são tranformações das células epiteliais da região equatorial do cristalino, que vão se sobrepondo continuamente, durante toda a vida. Daí, como no tronco de uma árvore, poder ser feito um histórico dessa estrutura viva: as camadas mais internas são as mais antigas, distinguindo-se um núcleo embrionário (formado entre o $1^{\circ}$ e o $3^{\circ}$ mês da gestação), um fetal (entre o $3^{\circ}$ e o $8^{\circ}$ ), um infantil (do fim da gestação à puberdade) e um adulto (a partir dessa época). Também a zona cortical, entre esse núcleo e o epitélio subcapsular cresce, ainda mais rapidamente, passando de $1 / 6$ de toda a espessura do cristalino, num adolescente, a $1 / 3$, num velho. Cobrindo o epitélio (que existe apenas na face anterior do cristalino), estrutura unicelular, sem camada basal, acha-se a cápsula, uma formação fina ( 4 a $23 \mu$ ), amorfa, mas bem resistente e altamente elástica. $\mathrm{O}$ cristalino é nutrido pelo humor aquoso, num processo de diálise, realizado pela semipermeabilidade da cápsula.

No pólo anterior, a curvatura é maior que na posterior (raios de curvatura respectivamente 8,5 a $14 \mathrm{~mm}$ e 4,5 a 7,5 mm, com médias 10 e 6) e a espessura total do cristalino chega a uns $4 \mathrm{~mm}$. O pólo anterior fica a uns 3 a $4 \mathrm{~mm}$ atrás da córnea. $\mathrm{O}$ eixo equatorial do cristalino (no encontro das faces anterior e posterior) tem uns 9 a $10 \mathrm{~mm}$, estendendo-se até aproximadamente $0,5 \mathrm{~mm}$ do corpo ciliar. As faces anterior e posterior do cristalino formam uma lente biconvexa, com índices de refração de aproximadamente 1,386 na camada cortical e 1,406 no núcleo (tornado ainda mais denso na senilidade) que, no ar, tem um poder dióptrico superior a $100 \mathrm{D}$, mas, quando separando o humor aquoso do corpo vítreo, cujos índices de refração $(1,336)$ são muito próximos dos de suas camadas externas, se reduz a um poder focal de umas + 19 D. Preso ao corpo ciliar por finos ligamentos suspensores (que se estendem por uns $2,5 \mathrm{~mm}$ de cada lado do equador) ou zônula , o cristalino pode ter suas curvaturas aumentadas pela contração do músculo (esfínter) ciliar, no processo chamado acomodação. Com isso, aumenta seu poder dióptrico, ajustando o ponto imagem do olho à posição da retina, quando objetos mais próximos são apresentados para discriminação visual.

Com o tempo, a flexibilidade do cristalino se reduz e o processo de acomodação vai, progressivamente, perdendo sua capacidade (presbiopia). Além disso, a transparência pode também se degradar por alterações metabólicas naturais (catarata senil), por distúrbios bioquímicos do plasma (e.g., catarata galactosêmica, diabética), por desagregações estruturais (cataratas por infravermelhos, por radiações ionizantes), por embebição pelo humor aquoso, em lesões capsulares (perfurações, ainda que pontiformes, dando cataratas traumáticas), etc.

\section{4 - Corpo vítreo}

É uma estrutura gelificada, composta basicamente de água (99\% de sua massa de cerca de 3,9 g), de ácido hialurônico e fibrilas colágenas. Transparente, mantém restos de vítreo embrionário e da artéria hialóide, formando o canal de Cloquet, entre o cristalino e o disco óptico, visível como uma fina teia em seu interior. Também células descamadas da retina e úvea anterior podem ser aí achadas. São elas e filamentos opacos do vítreo que dão as imagens de "moscas volantes", pequenas manchas que se movem com a rotação do olho.

\section{B - O sistema óptico suplementar}

Para regular a entrada de luz no olho e produzir ajustamentos ópticos (acomodação) há estruturas oculares, compondo a úvea anterior (a íris e o corpo ciliar).

\section{1 - Íris}

Situada à frente do cristalino, separa a câmara anterior e a posterior. Por sua forte pigmentação de variadas combinações (embora de apenas dois tipos de pigmentos, o dos cromócitos, de origem mesodérmica, amarelo-pardacentos; e o dos melanócitos, 
de origem ectodérmica, escuros) confere o que se conhece como "cor dos olhos" (azul, verde, castanha, cinzenta, etc.). Tem um estroma, com duas camadas mesodérmicas (a superficial e a profunda) na região periférica, ou "raiz"; e apenas a camada profunda, ectodérmica, na região pupilar. Mas esta é mais densa do que aquela, razão pela qual podem ocorrer desinserções na zona ciliar (raiz) da íris. Na borda pupilar possui um músculo liso, esfinctérico, de cuja contração se faz a miose (o esfínter da íris); e um de estrutura mioepitelial, dispondo-se radialmente, e que ajuda a produzir a dilatação da pupila (midríase), com o relaxamento do esfínter. A inervação motora da íris é autônoma, complexa, com fibras colinérgicas (parassimpáticas) e adrenérgicas (simpáticas) inervando tanto o esfínter quanto o músculo dilatador da pupila, embora se atribua ao primeiro a predominância de uma inervação parassimpática e à manutenção da tonicidade do segundo uma inervação simpática. De qualquer modo, a miose é principalmente induzida pela estimulação do sistema parassimpático (e menos pela inibição do simpático), enquanto a midríase é principalmente produzida pela inibição do parassimpático (e menos pela excitação do simpático). A sensibilidade da íris é dada por nervos ciliares curtos e longos, ramos do nervo nasociliar ou nasal, por sua vez originado da divisão oftálmica do trigêmeo, o V nervo intracranial (do qual, aliás, se origina a sensibilidade de todo o olho, anexos e regiões circunjacentes).

A face posterior da íris é recoberta por um epitélio que se continua com o da retina. Há vasos, em grande número e diferentes planos, originados de artérias ciliares posteriores longas e de ciliares anteriores (vindas pelos músculos oculares externos), formando o círculo arterial maior da íris.

\section{2 - Corpo ciliar}

É constituído por duas porções básicas: os processos ciliares, onde se produz o humor aquoso e o músculo ciliar, responsável pelo processo de acomodação. O corpo ciliar corresponde, externamente, a uma região que circunda o limbo por alguns milímetros. Aliás, quando esse anel perilímbico aparece violáceo (por injeção sanguínea em vasos que se dilatam) diagnostica-se a inflamação do corpo ciliar (ciclite), também reconhecida por ser muito dolorosa à palpação.

O músculo ciliar é a porção mais externa (periférica) do corpo ciliar, logo abaixo da esclera. As fibras são lisas, circulares e radiadas, mas há descrições de disposições mais complexas. A contração esfinctérica (mediada indiscutivelmente pelo sistema paras- simpático, embora exista uma controvérsia, de pouco interesse, sobre se também o simpático teria alguma ação sobre ela) dá um relaxamento da zônula com decorrente abaulamento das cápsulas do cristalino (principalmente a anterior) e, portanto, um aumento do poder dióptrico do olho.

Os processos ciliares são pregas de tecido conjuntivo frouxo, ricas em novelos vasculares (principalmente venosos), dispostas como franjas radiais (umas 70). A eles estão presos os delicados filamentos que se prendem ao cristalino.

\section{C - O sistema de nutrição e proteção}

\section{1 - Coróide}

Abaixo (ou atrás) da retina acha-se a coróide, um novelo vascular com a função de nutri-la. Coróide, corpo ciliar e íris possuem mesma origem embrionária e constituem a úvea, uma estrutura suscetível a sofrer inflamações (uveítes) que podem ser localizadas (irites e, ou ciclites: uveítes anteriores; e uveítes posteriores, ou coroidites, frequientemente associadas a acometimentos da retina suprajacente, as coriorretinites).

A coróide é constituída de fora do olho (esclera) para o seu interior (retina) por:

a - uma camada de tecido conjuntivo laminar, frouxo, com grandes espaços linfáticos, por onde passam vasos e nervos ciliares: a epicoróide, ou lâmina supracoroidiana;

b - a camada de coriocapilares, vasos enrodilhados (preponderantemente veias), entre fibras conjuntivas e elásticas, cromatóforos, fibras musculares lisas, nervos e lamelas (colágenas, elásticas); o sangue procede da artéria oftálmica (derivada da carótida interna), entrando no olho pelas ciliares posteriores curtas, saindo dele pelas veias vorticosas (ou ciliares posteriores) para as veias oftálmicas superior e inferior e daí ao seio cavernoso;

c - a membrana de Bruch, fina $(2 \mu)$, em contato com a retina.

\section{2 - Esclera ou esclerótica}

Do grego "skleros", duro, é o envoltório protetor do olho e que lhe dá sustentação. Formada por lamelas fibrosas de fibras conjuntivas colágenas e elásticas entrelaçadas irregularmente, em várias direções e densamente compactadas em feixes de uns 10 a $15 \mu$ de espessura e comprimento aproximadamente dez vezes maior, é uma camada opaca (branca), resistente, com cerca de $1 \mathrm{~mm}$ de espessura, praticamente avascular. É nela que se inserem os músculos oculares externos. 
Por ser quase inextensível, mantém o volume ocular praticamente inalterado, tornando as alterações de equilíbrio hidrodinâmico do olho um fator condicionante da pressão intra-ocular.

$\mathrm{Na}$ intimidade da esclera (substância própria, ou estroma da esclera), aparecem alguns vasos e nervos. Externamente, é recoberta por uma fina camada, elástica, delicada (episclera) e, internamente, por uma outra, também elástica, pardacenta (pela presença de cromatóforos), a lâmina fosca, sobre a qual existe uma camada de células endoteliais, já conside- radas como parte da úvea. Há solução de continuidade da capa escleral em vários locais: no pólo posterior, para a saída de axônios das células ganglionares (fibras do nervo óptico) em múltiplos fascículos, formando como que uma peneira, a lâmina crivosa, rodeada por outros pequenos orifícios para a entrada de artérias ciliares posteriores e nervos ciliares. As veias vorticosas saem do olho em trajetos oblíquos, em outras regiões, próximas ao equador, constituindo como que uns canalículos intraesclerais, que chegam até a uns $3 \mathrm{~mm}$ de comprimento.

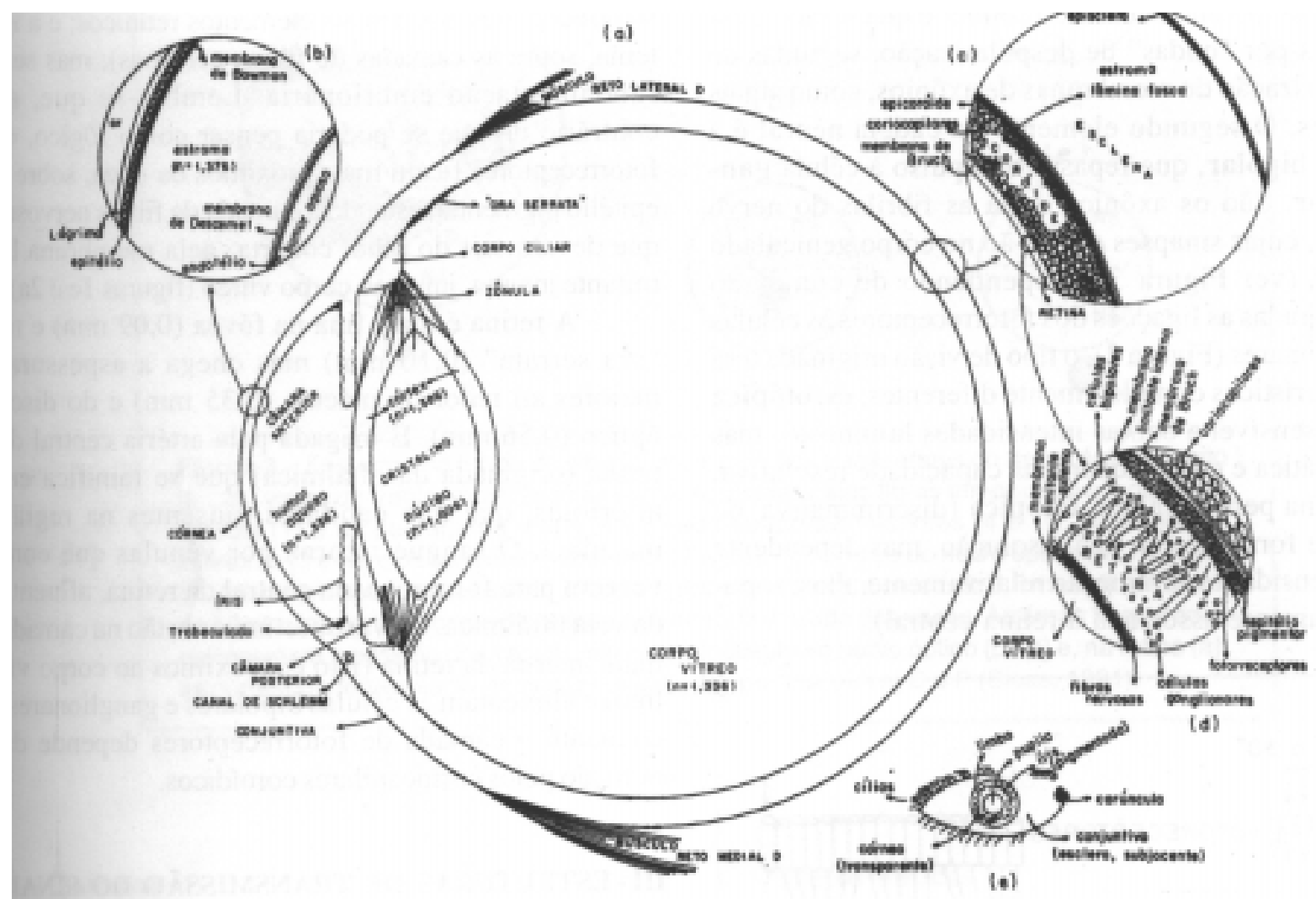

Figura 1 - Esquema de uma secção horizontal do olho (direito, vista de cima) com indicações das estruturas principais (a) e de constituições microscópicas da córnea (b), da esclera e coróide (c) e retina (d). As proporções não são rigorosamente mantidas. Em (e), referenciais externos, em vista frontal do olho.

\section{II - A ESTRUTURA DE TRANSFORMAÇÃO DA LUZ EM SINAL NEURAL}

A retina é a estrutura fundamental do olho, embora não possa subsistir sem as outras. Topografi- camente, divide-se numa parte periférica, atrófica e sem interesse, por ser insensível à luz, que vai desde a chamada "ora serrata" (internamente, a uns 6 a $8 \mathrm{~mm}$ atrás do limbo, e a uns $6 \mathrm{~mm}$ à frente do equador ocular) à borda da pupila, recobrindo o corpo ciliar e a 
face posterior da íris, freqüentemente assumida como um estrato da úvea anterior. A parte sensorial recobre todo o restante das camadas internas da úvea e também se subdivide numa porção "periférica" (em que predominam os fotorreceptores conhecidos como bastonetes e uma arquitetura de campos receptivos muito amplos) e numa "central" (em que são mais abundantes os cones).

Esses fotorreceptores representam o primeiro neurônio da organização sensorial visual, contendo pigmentos sensíveis à luz (rodopsina nos bastonetes, iodopsina nos cones) que ao se decomporem por ação dela numa proteína (opsina) e num carotenóide (relacionado a aldeídos da vitamina A) desencadeiam alterações do potencial elétrico celular e que serão transmitidas por "ondas" de despolarização, seguidas de repolarização de membranas de axônios, como sinais neurais. O segundo elemento da cadeia neural é a célula bipolar, que repassa o impulso à célula ganglionar. São os axônios desta as fibrilas do nervo óptico, cujas sinapses dar-se-ão no corpo geniculado lateral (ver Figura 3). Dependendo de como são estruturadas as ligações dos fotorreceptores às células ganglionares (Figura 2), o tipo de visão originada terá características completamente diferentes: escotópica (mais sensível a baixas intensidades luminosas, mas acromática e com paupérrima capacidade resolutiva, na retina periférica) e a fotópica (discriminativa de cores e formas, com boa resolução, mas dependente de intensidades luminosas relativamente altas, topograficamente associada à retina central).

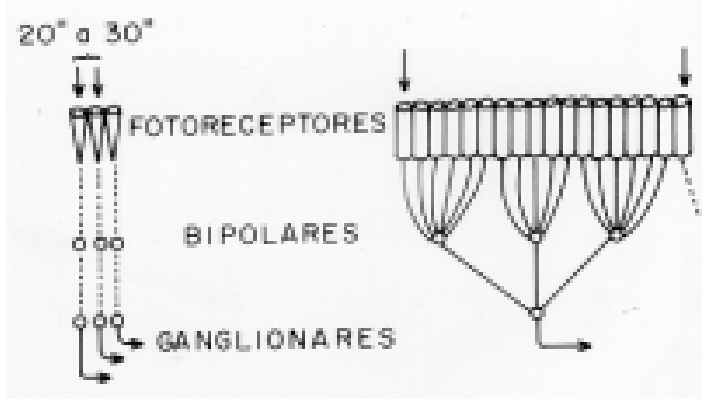

Figura 2 - Estruturação esquemática das ligações sinápticas da cadeia sensorial visual na retina central (à esquerda)) e na periférica (à direita). Na retina central, o campo receptivo é pequeno (20 a 30"), pelas conexões individualizadas e independentes, achadas para uns 2500 cones, no centro da fovéola $\left(0,1 \mathrm{~mm}\right.$ ou $\left.20^{\prime}\right)$. Na periferia, os campos receptivos são bem mais amplos.
A região central da retina, a mácula, tem uns 2 a $3 \mathrm{~mm}$ de diâmetro (o que corresponde a uns 9 a $13^{\circ}$ de abertura angular no campo visual), no centro da qual se acha a fóvea, compreendendo uma área de cerca de 1,5 $\mathrm{mm}$ de diâmetro (equivalente a uns $6^{\circ}$ ), cujo centro é a fovéola, região sem bastonetes ( 0,4 a 0,6 mm, ou 100' a 140' de arco).

Além dessa disposição "vertical", há associações entre os neurônios dessa cadeia, garantidas por células horizontais e amácrinas. Ocupando espaço entre os corpos celulares e seus filamentos, há uma rede de fibras neurogliais (de Müller) para sustentação, formando as chamadas "membranas limitantes da retina", descritas histologicamente (a externa, separando os fotorreceptores dos demais elementos retínicos; e a interna, sobre as camadas de fibras nervosas), mas sem fundamentação embrionária. Lembre-se que, ao contrário do que se poderia pensar como lógico, os fotorreceptores ficam mais próximos da úvea, sobre o epitélio pigmentar, estando a camada de fibras nervosas que devem sair do olho, coberta pela membrana limitante interna, junto ao corpo vítreo (figuras 1c e 2a).

A retina é mais fina na fóvea $(0,09 \mathrm{~mm})$ e na "ora serrata" $(0,10 \mathrm{~mm})$ mas chega a espessuras maiores ao redor da mácula $(0,35 \mathrm{~mm})$ e do disco óptico $(0,56 \mathrm{~mm})$. É irrigada pela artéria central da retina (originada da oftálmica) que se ramifica em arteríolas, que dão capilares (ausentes na região macular). O sangue retorna por vênulas que convergem para formar a veia central da retina, afluente da veia oftálmica. Os vasos retínicos estão na camada mais interna da retina (isto é, próximos ao corpo vítreo) e alimentam as células bipolares e ganglionares, enquanto a camada de fotorreceptores depende da nutrição pelos coriocapilares coroídicos.

\section{III - ESTRUTURAS DE TRANSMISSÃO DO SINAL NEURAL}

Depois de gerado na retina, o sinal neural será transmitido ao córtex visual pelas chamadas vias visuais. O que as caracteriza é a diversificação de suas partes constituintes, responsáveis por áreas específicas dos campos visuais de tal sorte que, pelo estudo destes, será possível a localização topográfica da afecção, no sistema nervoso central.

\section{A - Nervo óptico}

Os axônios das células ganglionares saem do olho pelo chamado disco óptico, situado a cerca de 
4 a $5 \mathrm{~mm}$ nasalmente à fóvea e $0,5 \mathrm{a} 1 \mathrm{~mm}$ acima dela. Esse disco geralmente é arredondado com diâmetro de $1,5 \mathrm{~mm}$, mas pode ser elíptico. O nervo óptico tem uns $25 \mathrm{~mm}$ de comprimento na posição intra-orbitária ou retrobulbar, sai da órbita pelo buraco óptico, tendo então em sua porção intracanalicular uns 4 a $10 \mathrm{~mm}$ e ainda se estende, na sua porção intracranial (cerca de $13 \mathrm{~mm}$ ) até o quiasma. Vai progressivamente se engrossando, desde a saída do olho ( 3 a $4 \mathrm{~mm}$ ) até o quiasma (4 a $7 \mathrm{~mm}$ ) pela mielina e meninges que o envolvem. Em secções transversais, mostra uma típica disposição de fibras correspondentes a regiões diferentes do olho (Figura 3).

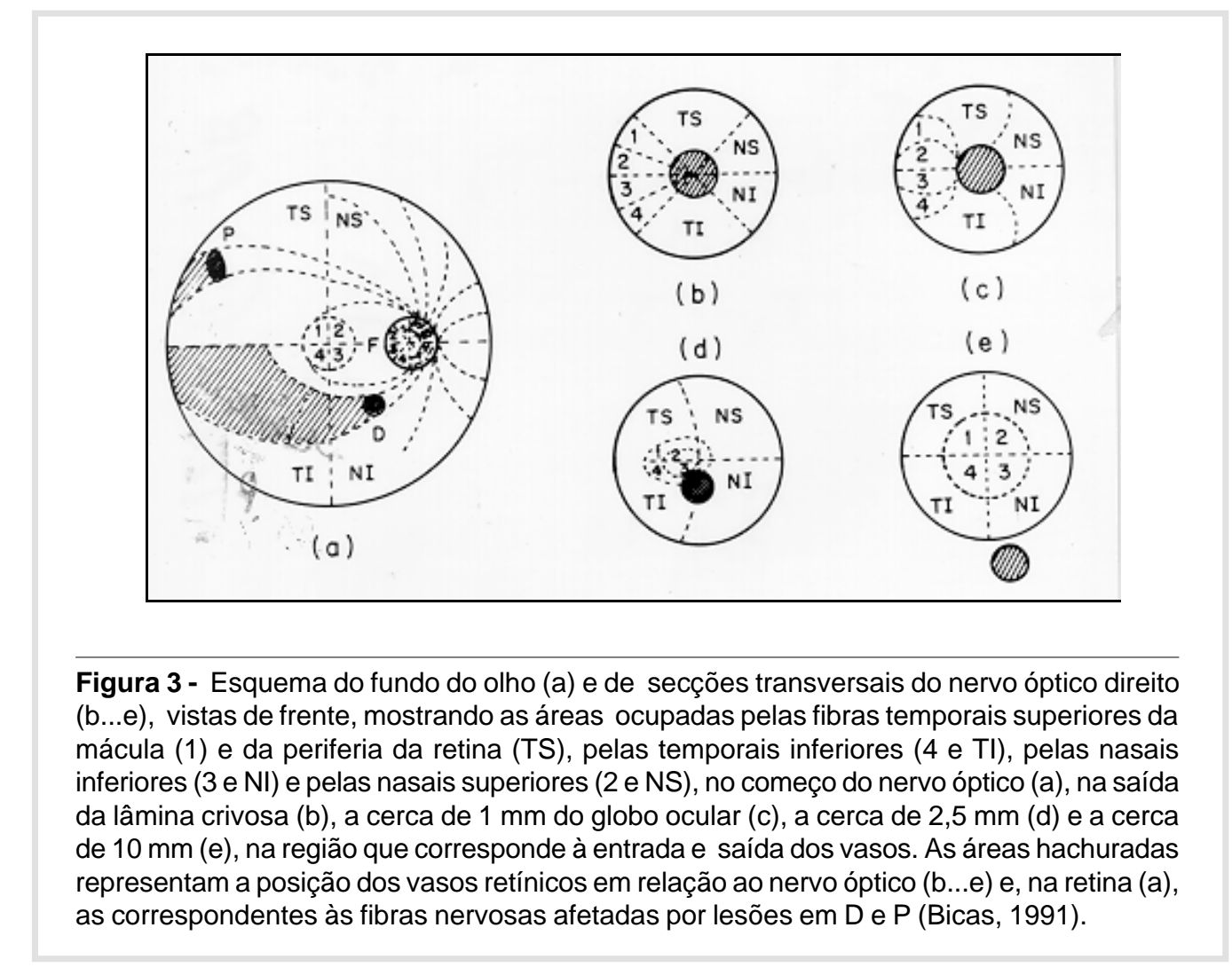

\section{B - Quiasma}

É uma estrutura achatada de forma aproximadamente quadrangular, correspondente ao cruzamento (parcial) dos nervos ópticos (do grego "khiasma", encruzilhada). Situa-se sobre a sela turca, acima da hipófise, abaixo do asssoalho do terceiro ventrículo, à frente do infundíbulo e com as artérias carótidas internas de cada lado. De modo simplificado, admite-se que as fibras temporais de cada retina seguem um trajeto direto e que as fibras nasais se cruzam. $\mathrm{Na}$ verdade, o esquema é um pouco mais complicado (Figura 4). Por esse cruzamento parcial das fibras retínicas é que se possibilita a visão binocular.

\section{C - Tratos ópticos}

Os feixes nervosos reorganizados depois do quiasma, constituem os tratos ópticos, contendo agora as metades homônimas (esquerda ou direita) e ipsilaterais das retinas de cada olho. Por exemplo, o trato óptico direito contém as fibras da retina temporal do OD (metade direita) e as da nasal do OE (também metade direita). Os tratos ópticos contornam os pedúnculos cerebrais e terminam nos corpos geniculados laterais, no pulvinar e no tubérculo quadrigêmeo anterior. São pequenos e bem protegidos, tornando-se, pois, pouco afetados, a não ser por compressões tumorais. 


\section{D - Corpos geniculados laterais}

Nessas estruturas ocorrem novas sinapses. Suas funções não são ainda bem conhecidas, mas as ligações neuronais ocorrem em disposições bem estratificadas e a organização se torna ainda maior.

\section{E - Radiações ópticas (vias geniculocalcarinas)}

Até os corpos geniculados laterais (e as outras estruturas, que constituem os centros ópticos primários), as vias visuais são chamadas "extracerebrais". Depois desses centros, são designadas como "intracerebrais". Os axônios das células do corpo geniculado lateral deixam-no por um feixe bem compacto, o pedúnculo óptico, no lobo temporal, passando, lateralmente, ao corno inferior do ventrículo lateral. Daí, divergem, mas constituindo feixes bem mais ordenados, com delimitações mais nítidas e homogêneas relativamente ao campo visual representado, ocupando uma área bem grande e, pois, muito vulnerável. As lesões dessas vias suprageniculares são, então, bem mais comuns, caracteristicamente hemianopsias homônimas (contralaterais), bem congruentes, com preservação do campo macular mas, mais freqüentemente, localizadas como quadrantanopsias.

As vias geniculocalcarinas são afetadas por lesões do lobo temporal, parietal e occipital.

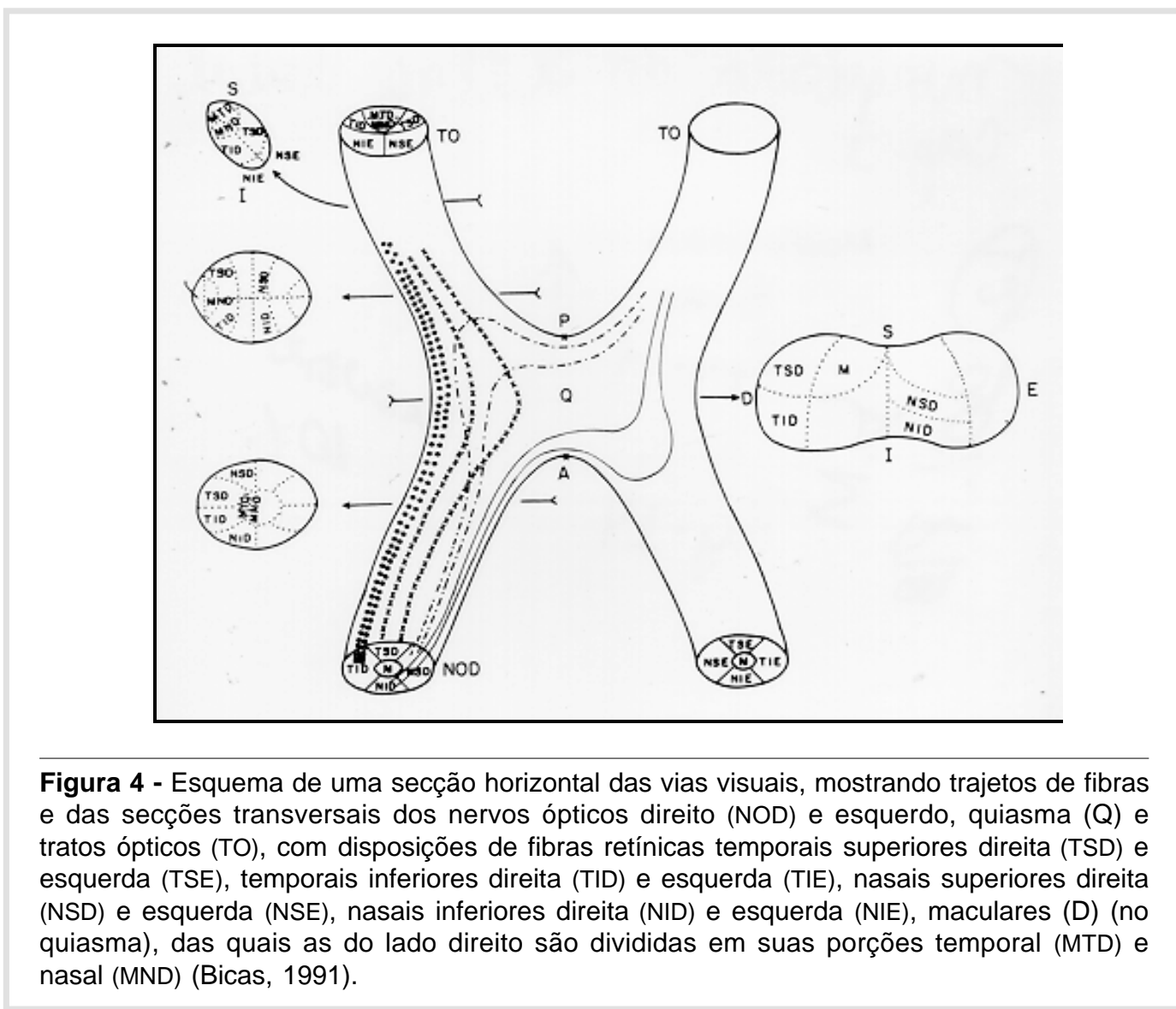

\section{IV - AS ESTRUTURAS DE DECODIFICAÇÃO DOS SINAIS}

A estação terminal das vias visuais se dá na superfície medial do lobo occipital, na área estriada (ou 17 de Brodmann) e na paraestriada (ou 18). Aí, a representação campimétrica visual é muito bem definida, e a da área macular desproporcionalmente grande, relativamente ao resto da retina. A área visual de um hemisfério cerebral (por exemplo, direito) é responsável pelos campos homônimos, contralaterais (esquerdos), ou seja, relacionados a vias visuais do lado nasal E e temporal D. Nessa área, dá-se a percepção visual: as sensações são aí arranjadas, no processo de "ver".

\section{V - AS ÁREAS DE ASSOCIAÇÃO}

Não obstante considerar-se que a visão se forme nas áreas estriada e paraestriada do lobo occipital, diz-se que esse nível é ainda "intermediário" 
e que outro, superior, onde se dá a integração e associação (processos psicológicos cognitivos de simbolismos e significados) se faz necessário para a compreensão daquilo que se vê.

Na verdade, já há indícios de associação nas áreas 17 e 18, mas considera-se a 19 (periestriada), ainda no lobo occipital, assim como as do giro angular (39) e supramarginal (40) no lobo parietal, outras no temporal e conexões entre os hemisférios cerebrais (corpo caloso), como as relacionadas a essas funções de reconhecimento visual. Lesões dessas áreas produzem distúrbios intelectivos como os da agnosia (a sensação, embora percebida, não se torna reconhecida em seu conteúdo de valores); afasia (distúrbio de formulação ou expressão do pensamento), principalmente a afasia sensorial, em que se dá uma incapacidade no reconhecimento de palavras escritas, completa (alexia) ou parcial (dislexia); apraxia (incapacidade de realização de um movimento ou ação desejada; ou por falta de formulação de um plano de seu desenvolvimento, ou por falha na sua aplicação), como no caso da incapacitação de desenhar ou mesmo copiar (sem que subsistam incapacidades visuais), às vezes confundida com uma agnosia espacial; ilusões (erros de interpretação); e alucinações (sensações ou percepções suscitadas por estímulos externos).

BICAS HEA. Morphology of the visual system. Medicina, Ribeirão Preto, 30: 7-15, jan./march 1997.

ABSTRACT: The morphology of the different structures related to the visual perception is described, accordingly to the respective function to which they serve: the organ for the reception of the luminous signal, including the optical system (cornea, anterior chamber, crystalline lens, vitreous body), its additional parts (iris, ciliary body) and the system for nourishment and protection (choroid, sclera). Then, the structures for the sensory transduction, the transformation of the light stimulus to a neural signal (retina) and that of its transmission (optic nerve, chiasm, optic tracts, lateral geniculate nucleus, optic radiations). At last, those for decoding the signals of the visual sensation to a perception (visual cortex) and those which connect such acquired informations to others (associative areas) so that a final comprehension results. With this systematized and extensive survey, the relative importance of each structure in the process of the visual integration is characterized.

UNITERMS: Ocular Structures. Visual Pathways. Vision.

\section{REFERÊNCIA BIBLIOGRÁFICA}

1 - BICAS HEA. Oftalmologia: Fundamentos. Ed. Contexto, São Paulo, 1991.
Recebido para publicação em 03/01/97

Aprovado para publicação em 30/01/97 